DOI: $10.19195 / 0137-1134.106 .12$

ANDRZEJ PAKUŁA

Uniwersytet Wrocławski

\title{
ROLA TERENOWEJ ADMINISTRACJI PUBLICZNEJ W ZAPOBIEGANIU SYTUACJOM KRYZYSOWYM
}

\section{UWAGI WSTĘPNE. ISTOTA BEZPIECZEŃSTWA PUBLICZNEGO}

Podniesiona $\mathrm{w}$ tytule tego tekstu problematyka bez wątpienia mieści się w szerszym obszarze tematycznym, w obszarze ochrony bezpieczeństwa publicznego. W myśl stosownych przepisów Konstytucji Rzeczypospolitej Polskiej ${ }^{1}$, Rzeczpospolita Polska strzeże niepodległości i nienaruszalności swojego terytorium, zapewnia wolność i prawa człowieka i obywatela oraz bezpieczeństwo obywateli, strzeże dziedzictwa narodowego oraz zapewnia ochronę środowiska, kierując się zasadą zrównoważonego rozwoju (art. 5), a także zobowiązuje władze publiczne do (między innymi) zwalczania chorób epidemicznych i zapobiegania negatywnym dla zdrowia skutkom degradacji środowiska (art. 68 ust. 4) oraz prowadzenia polityki zapewniającej bezpieczeństwo ekologiczne współczesnemu i przyszłym pokoleniom (art. 68 ust. 1). W literaturze przedmiotu podkreśla się, że „[t]roska o bezpieczeństwo, ład społeczny i gospodarczy, obrona przed wrogiem to wszakże takie zadania administracji publicznej, które mają charakter uniwersalny, niezależny od typu państwa i okresu historycznego"2.

W myśl jednej z definicji słownikowych bezpieczeństwo publiczne jest to „całość porządku i urządzeń społecznych chroniących państwo i obywateli przed zjawiskami groźnymi dla ładu prawnego; w węższym rozumieniu zn.: ochrona ustroju przed zamachami na podstawowe instytucje polityczne państwa"3.

S. Pikulski podkreśla, że bezpieczeństwo publiczne ujmować należy w kategorii wartości społecznej i to najwyższej, albowiem determinującej pewność

${ }^{1}$ Konstytucja Rzeczypospolitej Polskiej z dnia 2 kwietnia 1997 r., Dz.U. Nr 78, poz. 483 ze sprost. i ze zm.

2 A. Błaś, Zadania administracji publicznej, [w:] Nauka administracji, red. J. Boć, Wrocław 2013, s. 131.

3 Stownik języka polskiego, red. M. Szymczak, t. 1, Warszawa 1978, s. 147. 
codziennego życia obywateli we wszystkich jego obszarach ${ }^{4}$. Natomiast zdaniem J. Jeżewskiego bezpieczeństwo publiczne

może być rozumiane jako idealny stan braku zagrożenia w życiu zbiorowości i jednostek. W praktyce społecznej we współczesnym państwie stan taki realnie nie istnieje; występują natomiast w szerokiej skali dążenia do ochrony wartości i dóbr zbiorowych i indywidualnych. Te właśnie dążenia do ochrony lub nawet sama ochrona są pojęciowo utożsamiane bezpieczeństwem publicznym. W tym więc sensie bezpieczeństwo publiczne oznacza najogólniej stan gotowości właściwych organów administracji publicznej do przeciwdziałania zagrożeniom oraz do bezzwłocznego i skutecznego powstrzymywania działań godzących w dobro państwa, porządek publiczny oraz życie, zdrowie i mienie obywateli ${ }^{5}$.

A. Misiuk zaś konkluduje, że „Bezpieczeństwo publiczne jest to stan braku zagrożenia dla funkcjonowania organizacji państwowej i realizacji jej interesów, umożliwiający normalny, swobodny jej rozwój”'6.

Bezpieczeństwo publiczne zatem, jak syntetycznie konkluduje S. Pieprzny:

zawsze łączone jest z zagrożeniem, czyli niebezpieczeństwem. Swoista dychotomia tych pojęć wynika z faktu, że zagrożenie czy niebezpieczeństwo ma charakter pierwotny, zaś bezpieczeństwo ma wtórny charakter, albowiem, aby można mówić o bezpieczeństwie, muszą zaistnieć pozytywne zmiany w otaczającej rzeczywistości oddalające lub stymulujące potencjalne niebezpieczeństwo ${ }^{7}$.

\section{SYTUACJA KRYZYSOWA - SZCZEGÓLNA POSTAĆ ZAGROŻENIA BEZPIECZEŃSTWA PUBLICZNEGO. ZARZĄDZANIE KRYZYSOWE}

Szczególną postać zagrożenia stanowi bez wątpienia sytuacja kryzysowa, której zapobieganie należy do zakresu zadań publicznych administracji rządowej i samorządu terytorialnego. Stosowną regulację tego obszaru aktywności administracji publicznej zawiera ustawa z dnia 26 kwietnia 2007 r. o zarządzaniu kryzysowym ${ }^{8}$.

W myśl treści art. 1 ustawy o zarządzaniu określa ona organy właściwe w sprawach zarządzania kryzysowego oraz ich zadania i zasady działania w tej dziedzinie oraz zasady finansowania zadań zarządzania kryzysowego. Nie ulega wątpliwości, że podstawowymi pojęciami, wokół których zbudowana jest kon-

${ }^{4}$ S. Pikulski, Podstawowe zagadnienia bezpieczeństwa publicznego, [w:] Prawne i administracyjne aspekty bezpieczeństwa osób i porządku publicznego w okresie transformacji ustrojowo-gospodarczej, red. W. Bednarek, S. Pikulski, Olsztyn 2000, s. 101.

5 J. Jeż (Jeżewski), Bezpieczeństwo publiczne, [w:] Encyklopedia prawa, red. U. Kalina-Prasznic, Warszawa 2007, s. 56.

6 A. Misiuk, Administracja porzadku i bezpieczeństwa publicznego. Zagadnienia prawno-ustrojowe, Warszawa 2008, s. 17.

7 S. Pieprzny, Ochrona bezpieczeństwa i porządku publicznego w prawie administracyjnym, Rzeszów 2007, s. 13-14.

8 Tekst jedn. Dz.U. z 2013 r., poz. 1166 (dalej: ustawa o zarządzaniu). 
strukcja całej ustawy o zarządzaniu, są pojęcie sytuacji kryzysowej i pojęcie zarządzania kryzysowego.

Sytuacja kryzysowa została określona w art. 3 pkt 1 ustawy o zarządzaniu. Stosownie do treści tego przepisu jest to sytuacja wpływająca negatywnie na poziom bezpieczeństwa ludzi, mienia w znacznych rozmiarach lub środowiska, wywołująca znaczne ograniczenia w działaniu właściwych organów administracji publicznej ze względu na nieadekwatność posiadanych sił i środków. Natomiast zarządzanie kryzysowe, w myśl regulacji zawartej w art. 2 ustawy o zarządzaniu, to działalność organów administracji publicznej będąca elementem kierowania bezpieczeństwem narodowym, która polega na czterech obszarach aktywności:

- zapobieganiu sytuacjom kryzysowym,

- przygotowaniu do przejmowania nad nimi kontroli w drodze zaplanowanych działań,

— reagowaniu w przypadku wystąpienia sytuacji kryzysowych,

— usuwaniu skutków sytuacji kryzysowych oraz odtwarzaniu zasobów i infrastruktury krytycznej ${ }^{9}$.

\section{INSTRUMENTY ZAPOBIEGANIA SYTUACJOM KRYZYSOWYM}

W ujęciu A. Szymonika zapobieganie sytuacjom kryzysowym polega przede wszystkim na monitorowaniu, rejestrowaniu, identyfikowaniu zagrożeń i zjawisk mogących być ich źródłem, planowaniu działań zapobiegawczych, przygotowywaniu stosownych regulacji prawnych, edukowaniu społeczeństwa w zakresie przeciwdziałania zagrożeniom, wspieraniu stosownych badań, gromadzeniu odpowiednich zasobów, wprowadzaniu niezbędnych zachęt i sankcji finansowych ${ }^{10}$. Wypada jednakże podkreślić, że za najistotniejszy instrument ustawa o zarządzaniu uznaje akty planowania, mianowicie Krajowy Plan Zarządzania Kryzysowego, wojewódzkie, powiatowe i gminne plany zarządzania kryzysowego.

W myśl treści art. 5 ustawy o zarządzaniu w skład tych planów, niezależnie od poziomu, na którym są opracowane, wchodzi plan główny obejmujący:

— charakterystykę oraz ocenę ryzyka wystąpienia zagrożeń, w tym dotyczących infrastruktury krytycznej ${ }^{11}$ oraz mapy ryzyka i mapy zagrożeń;

9 Podobną klasyfikację obszarów zarządzania kryzysowego przyjmuje E. Bonusiak, Pojęcia podstawowe i zasady zrzadzania kryzysowego, [w:] Bezpieczeństwo wewnętrzne państwa, red. E. Ura, S. Pieprzny, Rzeszów 2015, s. 278.

10 A. Szymonik, Organizacja i funkcjonowanie systemów bezpieczeństwa, Warszawa 2011, s. $64-65$.

11 W myśl treści art. 3 pkt 2 ustawy o zarządzaniu, infrastruktura krytyczna są to systemy oraz wchodzące $\mathrm{w}$ ich skład powiązane z sobą funkcjonalnie obiekty, w tym obiekty budowlane, urządzenia, instalacje, usługi kluczowe dla bezpieczeństwa państwa i jego obywateli oraz służące zapewnieniu sprawnego funkcjonowania organów administracji publicznej, a także instytucji i przedsię- 
— zadania i obowiązki uczestników zarządzania kryzysowego w formie siatki bezpieczeństwa;

— zestawienie sił i środków planowanych do wykorzystania w sytuacjach kryzysowych;

— zadania określone planami działań krótkoterminowych, określonymi w art. 92 ustawy z dnia 17 kwietnia 2001 r. - Prawo ochrony środowiska.

Następnymi elementami składowymi planów zarządzania kryzysowego są zespoły przedsięwzięć na wypadek sytuacji kryzysowej ${ }^{12}$ oraz stosowne załączniki funkcjonalne ${ }^{13}$. Plany zarządzania kryzysowego podlegają systematycznej aktualizacji, a cykl planowania nie może być dłuższy niż dwa lata.

\section{ORGANY WŁAŚCIWE W SPRAWACH ZARZĄDZANIA KRYZYSOWEGO}

\section{RADA MINISTRÓW}

Na szczeblu ogólnokrajowym (centralnym) zadania z zakresu zarządzania kryzysowego realizuje przede wszystkim Rada Ministrów (art. 7 ust. 1 ustawy o zarządzaniu) przy pomocy Rządowego Zespołu Zarządzania Kryzysowego (art. 8 ustawy o zarządzaniu) oraz Rządowego Centrum Bezpieczeństwa, będącego państwową jednostką organizacyjną, podległą Prezesowi Rady Ministrów (art. 10-11a ustawy o zarządzaniu). Ustawa o zarządzaniu wprowadza także stosowną regulację odnośnie do zadań i kompetencji terenowych organów administracji publicznej.

biorstw. Obejmuje ona systemy: zaopatrzenia w energię, surowce energetyczne i paliwa, łączności, sieci teleinformatycznych, finansowe, zaopatrzenia w żywność, zaopatrzenia w wodę, ochrony zdrowia, transportowe, ratownicze, zapewniające ciągłość działania administracji publicznej, produkcji, składowania, przechowywania i stosowania substancji chemicznych i promieniotwórczych, w tym rurociągi substancji niebezpiecznych.

12 Są to zadania w zakresie monitorowania zagrożeń, tryb uruchamiania niezbędnych sił i środków do uczestniczących w realizacji planowanych przedsięwzięć na wypadek sytuacji kryzysowej, procedury reagowania kryzysowego określające sposób postępowania w sytuacjach kryzysowych, współdziałania między podmiotami uczestniczącymi w realizacji planowanych przedsięwzięć na wypadek sytuacji kryzysowych.

13 Są to: procedury realizacji zadań z zakresu zarządzania kryzysowego, w tym związane z ochroną infrastruktury krytycznej, organizacja łączności, organizacja systemu monitorowania zagrożeń, ostrzegania i alarmowania, zasady informowania ludności o zagrożeniach i sposobach postępowania na wypadek zagrożeń, organizacja ewakuacji z obszarów zagrożonych, organizacja ratownictwa, opieki medycznej, pomocy społecznej oraz pomocy psychologicznej, organizacja ochrony przed zagrożeniami charakterystycznymi dla danego obszaru, wykaz zawartych umów i porozumień związanych z realizacją zadań ujętych w planie zarządzania kryzysowego, zasady oraz tryb oceniania i dokumentowania szkód, procedury uruchamiania rezerw państwowych, wykaz infrastruktury krytycznej znajdującej się odpowiednio na terenie województwa, powiatu lub gminy, objętej planem zarządzania kryzysowego, priorytety w zakresie ochrony oraz odtwarzania infrastruktury krytycznej. 


\section{WOJEWODA}

Na mocy art. 14 ustawy o zarządzaniu organem właściwym w sprawach zarządzania kryzysowego na obszarze województwa jest wojewoda, który:

— kieruje monitorowaniem, planowaniem, reagowaniem i usuwaniem skutków zagrożeń na terenie województwa;

- realizuje zadania z zakresu planowania cywilnego ${ }^{14}$, w tym wydaje starostom zalecenia do powiatowych planów zarządzania kryzysowego, zatwierdza powiatowe plany zarządzania kryzysowego, przygotowuje i przedkłada do zatwierdzenia ministrowi właściwemu do spraw administracji publicznej wojewódzki plan zarządzania kryzysowego, wykonuje wytyczne do wojewódzkiego planu zarządzania kryzysowego (wydawane w drodze zarządzenia przez ministra właściwego do spraw administracji publicznej, w uzgodnieniu z ministrem właściwym do spraw wewnętrznych, po zasięgnięciu opinii dyrektora Rządowego Centrum Bezpieczeństwa - art. 14 ust. 3 ustawy o zarządzaniu);

— zarządza, organizuje i prowadzi szkolenia, ćwiczenia i treningi z zakresu zarządzania kryzysowego;

— wnioskuje o użycie pododdziałów Sił Zbrojnych Rzeczypospolitej Polskiej do wskazanych w ustawie o zarządzaniu działań;

- wykonuje przedsięwzięcia wynikające z dokumentów planistycznych realizowanych $\mathrm{w}$ ramach planowania operacyjnego w województwie;

— zapobiega i przeciwdziała zdarzeniom o charakterze terrorystycznym oraz usuwa ich skutki;

— współdziała z szefem Agencji Bezpieczeństwa Wewnętrznego w zakresie zapobiegania i przeciwdziałania skutków zdarzeniom o charakterze terrorystycznym oraz usuwania ich skutków;

— organizuje wykonanie zadań z zakresu ochrony infrastruktury krytycznej.

Wojewoda przewidziane dla niego zadania w zakresie zarządzania kryzysowego wykonuje we współpracy z właściwymi organami administracji publicznej (art. 14 ust. 5 ustawy o zarządzaniu) oraz przy pomocy wojewódzkiego zespołu zarządzania kryzysowego (art. 14 ust. 7-12 ustawy o zarządzaniu), powoływanego przez wojewodę, który określa także jego skład, organizację, siedzibę oraz tryb pracy. Do zadań tego organu pomocniczego należy w szczególności ocena występujących i potencjalnych zagrożeń mogących mieć wpływ na bezpieczeństwo publiczne i prognozowanie tych zagrożeń, przygotowywanie propozycji działań i przedstawianie wojewodzie wniosków dotyczących wykonania, zmiany lub zaniechania działań ujętych w wojewódzkim planie zarządzania kryzysowego,

14 W myśl art. 3 pkt 4 ustawy o zarządzaniu planowanie cywilne obejmuje całokształt przedsięwzięć organizacyjnych mających na celu przygotowanie administracji publicznej do zarządzania kryzysowego oraz planowanie w zakresie wspierania Sił Zbrojnych Rzeczypospolitej Polskiej w razie ich użycia, a także planowanie wykorzystania tych Sił do realizacji zadań z zakresu zarządzania kryzysowego. 
przekazywanie do wiadomości publicznej informacji związanych z zagrożeniami, opiniowanie wojewódzkiego planu zarządzania kryzysowego. Podstawowy skład zespołu tworzą wojewoda jako jego przewodniczący, kierownik komórki właściwej w sprawach zarządzania kryzysowego w urzędzie wojewódzkim jako zastępca przewodniczącego, szef wojewódzkiego sztabu wojskowego lub jego przedstawiciel oraz inne osoby wskazane przez przewodniczącego w zależności od potrzeb $\mathrm{z}$ grona podmiotów wskazanych $\mathrm{w}$ ustawie o zarządzaniu ${ }^{15}$. Ponadto $\mathrm{w}$ jego skład mogą wchodzić: przedstawiciel samorządu województwa wyznaczony przez marszałka województwa oraz inne osoby zaproszone przez przewodniczącego. Ustawa o zarządzaniu, w art. 14 ust. 6, określa także podstawowe zadania komórki organizacyjnej urzędu wojewódzkiego właściwej w sprawach zarządzania kryzysowego, natomiast na mocy art. 16 ustanawia wojewódzkie centrum zarządzania kryzysowego, do którego zadań należy:

— pełnienie całodobowego dyżuru w celu zapewnienia przepływu informacji na potrzeby zarządzania kryzysowego;

— współdziałanie z centrami zarządzania kryzysowego organów administracji publicznej;

- nadzór nad funkcjonowaniem systemu wykrywania i alarmowania oraz systemu wczesnego ostrzegania ludności;

— współpraca z podmiotami realizującymi monitoring środowiska;

— współdziałanie z podmiotami prowadzącymi akcje ratownicze, poszukiwawcze i humanitarne;

— dokumentowanie działań podejmowanych przez centrum;

- realizacja zadań stałego dyżuru na potrzeby podwyższania gotowości obronnej państwa;

— wykonywanie zadań określonych w art. 22 ust. 1 i 2 ustawy z dnia 24 lipca 2015 r. - Prawo o zgromadzeniach.

Ustawodawca jedynie uzupełniająco ujmuje rolę samorządu województwa, stwierdzając $\mathrm{w}$ art. 15 ustawy o zarządzaniu, że zarząd województwa uczestniczy w realizacji zadań z zakresu zarządzania kryzysowego, w tym planowania cywilnego, wynikających z jego kompetencji. W literaturze przedmiotu wyrażono pogląd, iż stan taki oznacza brak po stronie organów samorządu województwa samodzielnych kompetencji i marginalny wpływ tych organów na podejmowane decyzje w obszarze zarządzania kryzysowego ${ }^{16}$.

15 Są to: kierownicy zespolonych służb, inspekcji i straży wojewódzkich, osoby zatrudnione w urzędzie wojewódzkim lub w jednostkach organizacyjnych służb, inspekcji i straży wojewódzkich, osoby zatrudnione w regionalnych zarządach gospodarki wodnej, wojewódzkich zarządach melioracji i urządzeń wodnych oraz Instytucie Meteorologii i Gospodarki Wodnej.

16 J. Jedynak, Udziat administracji samorzadowej szczebla lokalnego w zarzadzaniu kryzysowym oraz w stanie nadzwyczajnym klęski żywiołowej, [w:] Rola i znaczenie zarzadzania kryzysowego w systemie bezpieczeństwa państwa, red. E. Ura, S. Pieprzny, J. Jedynak, Rzeszów 2013, s. 105. 
Wypada w tym miejscu odnieść się także do ogólnej regulacji statusu wojewody jako przedstawiciela Rady Ministrów, zawartej w rozdziale 2 ustawy z dnia 23 stycznia 2009 r. o wojewodzie i administracji rządowej w województwie ${ }^{17}$, w szczególności w art. 22 pkt 2-4 oraz w art. 25 ust. 1 i 2. Na mocy wskazanych przepisów wojewoda zapewnia współdziałanie wszystkich organów administracji rządowej i samorządowej działających w województwie i kieruje ich działalnością w zakresie zapobiegania zagrożeniu życia, zdrowia lub mienia oraz zagrożeniom środowiska, bezpieczeństwa państwa i utrzymania porządku publicznego i ochrony praw obywatelskich, a także zapobiegania klęskom żywiołowym i innym nadzwyczajnym zagrożeniom oraz zwalczania i usuwania ich skutków na zasadach określonych w odrębnych przepisach, dokonuje oceny stanu zabezpieczenia przeciwpowodziowego województwa, opracowuje plan operacyjny ochrony przed powodzią oraz ogłasza i odwołuje pogotowie i alarm przeciwpowodziowy. Wojewoda może wydawać polecenia obowiązujące wszystkie organy administracji rządowej działające w województwie, a w sytuacjach nadzwyczajnych, do których zalicza się także sytuacje kryzysowe, obowiązujące również organy samorządu terytorialnego, powiadamiając niezwłocznie o wydanych poleceniach właściwego ministra. W odniesieniu do zarządzania kryzysowego daje się niewątpliwie zauważyć zróżnicowanie charakteru stosownych zadań wojewody. $\mathrm{W}$ fazie przygotowania i zapobiegania są to zadania o charakterze koordynacyjnym, kreujące instrumenty niezbędne do sprawnego współdziałania. W fazie zaś reagowania na zaistniałą sytuację kryzysową i usuwania jej skutków wojewoda jednoznacznie zostaje mocą stosownych przepisów usytuowany na pozycji pomiotu sprawującego kierownictwo.

\section{STAROSTA}

Na terenie powiatu, na mocy art. 17 ust. 1 i 2 ustawy o zarządzaniu, organem właściwym w sprawach zarządzania kryzysowego jest starosta jako przewodniczący zarządu powiatu. Do zadań tego organu we skazanym zakresie należy:

- kierowanie monitorowaniem, planowaniem, reagowaniem i usuwaniem skutków zagrożeń na terenie powiatu;

— realizacja zadań z zakresu planowania cywilnego, w tym opracowywanie i przedkładanie wojewodzie do zatwierdzenia powiatowego planu zarządzania kryzysowego, realizacja zaleceń do powiatowego planu zarządzania kryzysowego, wydawanie organom gminy zaleceń do gminnego planu zarządzania kryzysowego, zatwierdzanie gminnego planu zarządzania kryzysowego;

— zarządzanie, organizowanie i prowadzenie szkoleń, ćwiczeń i treningów z zakresu zarządzania kryzysowego;

- wykonywanie przedsięwzięć wynikających z planu operacyjnego funkcjonowania powiatów i miast na prawach powiatów;

\footnotetext{
17 Tekst jedn. Dz.U. z 2015 r., poz. 525 z późn. zm.
} 
- zapobieganie i przeciwdziałanie zdarzeniom o charakterze terrorystycznym oraz usuwanie ich skutków;

— współdziałanie z szefem Agencji Bezpieczeństwa Wewnętrznego w zakresie przeciwdziałania i zapobiegania zdarzeniom o charakterze terrorystycznym oraz usuwania ich skutków;

— organizacja i realizacja zadań z zakresu ochrony infrastruktury krytycznej.

Jest rzeczą oczywistą, że starosta nie został umocowany do bezpośredniego wnioskowania o użycie Sił Zbrojnych Rzeczypospolitej Polskiej, aczkolwiek wydaje się dopuszczalne zainspirowanie przez starostę stosownego wniosku wojewody.

Starosta zadania w zakresie zarządzania kryzysowego wykonuje przy pomocy powiatowej administracji zespolonej i jednostek organizacyjnych powiatu (art. 17 ust. 3 ustawy o zarządzaniu) oraz powiatowego zespołu zarządzania kryzysowego, powoływanego przez starostę, który określa jego skład, organizację, siedzibę oraz tryb pracy (art. 17 ust. 4 ustawy o zarządzaniu). Zespół wykonuje na terenie powiatu zadania analogiczne do tych przewidzianych dla wojewódzkiego zespołu zarządzania kryzysowego (art.17 ust. 5 ustawy o zarządzaniu). Pracami zespołu kieruje starosta, a w jego skład wchodzą osoby powołane przez starostę, zatrudnione $\mathrm{w}$ starostwie powiatowym, powiatowych jednostkach organizacyjnych lub jednostkach organizacyjnych stanowiących aparat pomocniczy kierowników zespolonych służb, inspekcji i straży powiatowych, a także przedstawiciele społecznych organizacji ratowniczych (art. 17 ust. 6 ustawy o zarządzaniu), w skład zespołu mogą wchodzić także inne osoby zaproszone przez starostę (art. 17 ust. 7 ustawy o zarządzaniu).

W odróżnieniu od regulacji odnoszącej się do wojewody ustawa o zarządzaniu nie określa żadnych zadań dla komórki organizacyjnej starostwa powiatowego mającej zajmować się sprawami zarządzania kryzysowego, ustanawia zaś, mocą art. 18, analogicznie do przypadku województwa, powiatowe centrum zarządzania kryzysowego. Podmiot ten zapewnia przepływ informacji na potrzeby zarzadzania kryzysowego i wykonuje, na terenie powiatu, zadania przewidziane dla wojewódzkiego centrum zarządzania kryzysowego. Organizację, siedzibę oraz tryb pracy powiatowego centrum zarządzania kryzysowego, w tym sposób całodobowego alarmowania członków zespołu zarządzania kryzysowego oraz sposób zapewnienia całodobowego obiegu informacji w sytuacjach kryzysowych, określa starosta. W miejscowościach będących jednocześnie siedzibami powiatów i miast na prawach powiatu, na podstawie porozumienia zawartego między tymi jednostkami samorządu terytorialnego, może być tworzone wspólne centrum zarządzania kryzysowego obejmujące zasięgiem działania obszar obu tych jednostek samorządu terytorialnego. Podobnie jak w przypadku wojewody zarządzanie kryzysowe w powiecie wypada ująć także w kontekście pozycji starosty określonej w ustawie z dnia 5 czerwca 1998 r. o samorządzie powiatowym ${ }^{18}$, w szczególności w art. 35

18 Tekst jedn. Dz.U. z 2015 r., poz.1445 z późn. zm. 
ust. 2 i 3. Stosownie do treści powołanej regulacji starosta jest zwierzchnikiem powiatowych służb, inspekcji oraz straży i w związku z tym, między innymi, zatwierdza programy ich działania, uzgadnia wspólne działanie tych jednostek na obszarze powiatu, a w sytuacjach szczególnych, do których bez wątpienia należą sytuacje kryzysowe, kieruje wspólnymi działaniami tych jednostek. Podobnie zatem jak w przypadku wojewody w odniesieniu do zarządzania kryzysowego dają się wyróżnić zadania o charakterze koordynacyjnym i kierowniczym.

\section{WÓJT (BURMISTRZ, PREZYDENT MIASTA)}

Stosownie do regulacji zawartej w art. 19 ustawy o zarządzaniu organem właściwym w sprawach zarządzania kryzysowego na terenie gminy jest wójt (burmistrz, prezydent miasta), który:

— kieruje monitorowaniem, planowaniem, reagowaniem i usuwaniem skutków zagrożeń na terenie gminy;

— realizuje zadania z zakresu planowania cywilnego, w tym wykonuje zalecenia do gminnego planu zarządzania kryzysowego, opracowuje i przedkłada staroście do zatwierdzenia gminny plan zarządzania kryzysowego, zarządza, organizuje i prowadzi szkolenia, ćwiczenia i treningi z zakresu zarządzania kryzysowego, wykonuje przedsięwzięcia wynikające z planu operacyjnego funkcjonowania gmin i gmin o statusie miasta, zapobiega i przeciwdziała zdarzeniom o charakterze terrorystycznym oraz usuwa ich skutki, współdziała z szefem Agencji Bezpieczeństwa Wewnętrznego w zakresie przeciwdziałania i zapobiegania zdarzeniom o charakterze terrorystycznym oraz usuwania ich skutków, organizuje i realizuje zadania z zakresu ochrony infrastruktury krytycznej.

Zadania z zakresu zarządzania kryzysowego wójt (burmistrz, prezydent miasta) wykonuje przy pomocy komórki organizacyjnej urzędu gminy (miasta) właściwej w sprawach zarządzania kryzysowego oraz organu pomocniczego w zapewnieniu wykonywania tych zadań - gminnego zespołu zarządzania kryzysowego. Wójt (burmistrz, prezydent miasta) określa skład, organizację, siedzibę oraz tryb pracy zespołu. Zespół wykonuje na terenie gminy zadania przewidziane dla wojewódzkiego zespołu zarządzania kryzysowego. Wójt (burmistrz, prezydent miasta) kieruje pracami zespołu i powołuje jego członków spośród osób zatrudnionych w urzędzie gminy (miasta), gminnych (miejskich) jednostkach organizacyjnych lub jednostkach pomocniczych, pracowników zespolonych służb, inspekcji i straży, skierowanych przez przełożonych do wykonywania zadań w tym zespole na wniosek wójta (burmistrza, prezydenta miasta), a także przedstawicieli społecznych organizacji ratowniczych. W skład zespołu mogą wchodzić także inne osoby zaproszone przez wójta (burmistrza, prezydenta miasta).

Ustawodawca nie wymaga tworzenia w gminie (mieście) gminnego (miejskiego) centrum zarządzania kryzysowego. Treść art. 20 ust. 1 ustawy o zarządzaniu zadania przewidziane w powiecie i w województwie dla takich centrów 
nakłada na wójta (burmistrza, prezydenta miasta), dopuszczając jednakże, w ust. 2 tego artykułu możliwość utworzenia gminnego (miejskiego) centrum zarządzania kryzysowego. Ponadto na mocy art. 31 b ustawy z dnia 8 marca 1990 r. o samorządzie gminnym ${ }^{19}$ wójt (burmistrz, prezydent miasta) może, jeżeli w inny sposób nie można usunąć bezpośredniego niebezpieczeństwa dla życia ludzi bądź dla mienia, zarządzić ewakuację z obszarów bezpośrednio zagrożonych.

\section{PREZYDENT MIASTA NA PRAWACH POWIATU}

Należy także podnieść problem miast na prawach powiatu. Zgodnie z treścią art. 92 ustawy o samorządzie powiatowym miasto na prawach powiatu jest w sensie ustrojowym gminą, zadaniowo zaś - gminą i powiatem jednocześnie. W odniesieniu do zarządzania kryzysowego oznacza to, że prezydent takiego miasta wykonuje zadania $\mathrm{z}$ tego obszaru przypisane mu jako prezydentowi miasta i jednocześnie te, które są przypisane staroście.

Ustawa o zarządzaniu w art. 20 stanowi, że organy właściwe w sprawach zarządzania kryzysowego mają prawo żądania udzielenia informacji, gromadzenia i przetwarzania danych niezbędnych do realizacji zadań z zakresu zarządzania kryzysowego. Treść art. 22 zawiera zezwolenie dla ministrów kierujących działami administracji rządowej, kierowników urzędów centralnych, wojewodów, starostów i wójtów (burmistrzów, prezydentów miast) do powoływania ekspertów do udziału w pracach właściwych zespołów zarządzania kryzysowego. Na mocy zaś art. 23 ust. 1, w zależności od skali zagrożenia atakiem o charakterze terrorystycznym lub sabotażowym, Prezes Rady Ministrów, ministrowie, kierownicy urzędów centralnych i wojewodowie mogą w drodze zarządzenia wprowadzić odpowiedni stopień alarmowy. Niezmiernie ważne jest ustawowe określenie podmiotu zobowiązanego do podjęcia działań w zakresie zarządzania kryzysowego. W myśl art. 21 ustawy o zarządzaniu obowiązek podjęcia takich działań spoczywa na tym organie właściwym w sprawach zarządzania kryzysowego, który pierwszy otrzymał informację o wystąpieniu zagrożenia. Organ ten niezwłocznie informuje o zaistniałym zdarzeniu organy odpowiednio wyższego i niższego szczebla, przedstawiając jednocześnie swoją ocenę sytuacji oraz informację o zamierzonych działaniach.

\section{UWAGI KOŃCOWE}

W podsumowaniu wypada stwierdzić, że ustawa o zarządzaniu istotną rolę przyznaje organom terenowym, wojewodom oraz starostom i wójtom (burmistrzom, prezydentom miast), marginalizując przy tym rolę organów stanowiących (rad i sejmików) i kolegialnych (zarządów powiatów i województw) jednostek

19 Tekst jedn. Dz.U. z 2015 r., poz. 1515 z późn. zm. 
samorządu terytorialnego. Jednocześnie konstruuje szczególną, wyłącznie do celów zarządzania kryzysowego, strukturę organów właściwych w tym zakresie. Struktura ta zbliżona jest do układu hierarchicznego, czego wyrazem jest udzielanie przez organy usytuowane na wyższym szczeblu podziału terytorialnego kraju organom usytuowanym na szczeblu niższym tego podziału i to niezależnie, czy są to organy administracji rządowej czy samorządu terytorialnego, zaleceń co do treści planów zarządzania kryzysowego oraz zatwierdzanie przez organy usytuowane wyżej w podziale terytorialnym planów zarządzania kryzysowego organów usytuowanych niżej w tym podziale, także niezależnie od charakteru ustrojowego tych organów. Stan taki niewątpliwie budzi pewne wątpliwości. W ujęciu Z. Duniewskiej, M. Górskiego, B. Jaworskiej-Dębskiej, E. Olejniczak-Szałowskiej i M. Stahl zalecenia te nie mają charakteru normatywnego i nie mogą być prawnie wiążące dla organów powiatów i gmin, nie są także aktami kierownictwa wewnętrznego ${ }^{20}$. W ujęciu zaś S. Pieprznego rozwiązanie takie wynika ze specyfiki planowania, ma na celu zagwarantowanie spójności planów na poszczególnych szczeblach podziału terytorialnego państwa, dawać rękojmię stworzenia spójnego systemu zarządzania kryzysowego ${ }^{21}$. Kwestię tę podniósł także w jednym z wyroków Trybunał Konstytucyjny, stwierdzając, że

[k]ierunki działania wynikające $\mathrm{z}$ wniosków z raportu są uwzględniane $\mathrm{w}$ planach zarządzania kryzysowego, w tym także w planach powiatowych i gminnych, opracowywanych przez organy jednostek samorządu terytorialnego. Należy jednak zauważyć, że „uwzględniania” kierunków działania raportu w planach zarządzania kryzysowego na niższych szczeblach nie można porównywać $\mathrm{z}$ wiązaniem normami prawnymi zawartymi w aktach normatywnych. To uwzględnianie oznacza zachowanie zgodności treści planów różnych szczebli. [...] Plany zarządzania kryzysowego powinny być ze sobą spójne co do celów działania. [...] Dzięki wskazanym dokumentom wyjściowym organy zarządzania kryzysowego mają możliwość wpływania na zawartość planów sporządzanych na niższym szczeblu, a to powinno zapewnić spójność poszczególnych planów oraz ujednolicenie celów działania i zasobów, które służą do ich osiągnięcia 22 .

Wydaje się zatem, że można przyjąć stanowisko wyrażone w literaturze przedmiotu, w myśl którego, pomimo wątpliwości co do prawnego charakteru zaleceń, starostowie nie mogą pominąć zaleceń wojewodów, a wójtowie (burmistrzowie, prezydenci miast) zaleceń starostów ${ }^{23}$, aczkolwiek prowadzi to pośrednio do podporządkowania wójta (burmistrza, prezydenta miasta) staroście, a tego ostatniego

20 Z. Duniewska et al., Plany, strategie, programy i inne zbliżone formy prawne działania administracji, [w:] Podmioty administracji publicznej i prawne formy ich działania. Studia i materiaty z Konferencji Naukowej poświęconej jubileuszowi 80. urodzin Profesora Eugeniusza Ochendowskiego, Torun 2005, s. $141 \mathrm{n}$.

21 S. Pieprzny, System zarządzania kryzysowego — analiza wybranych zagadnień, [w:] Zarzadzanie kryzysowe w administracji publicznej, red. J. Kisielnicki et al., Warszawa 2010, s. 129-130.

22 Wyrok Trybunału Konstytucyjnego z dnia 3 lipca 2012 r., OTK-A 2012, nr 7, poz. 74.

23 E. Bonusiak, Zarządzanie kryzysowe na szczeblu powiatu, [w:] Bezpieczeństwo wewnętrzne państwa, s. 305. 
— wojewodzie, ale przecież tylko w określonym merytorycznym, zadaniowym, nie zaś ustrojowym obszarze, choć pewnego „zaburzenia” tego ustrojowego obszaru nie da się nie zauważyć. Zarządzanie kryzysowe jednakże, jako kryzysowe właśnie, to bez wątpienia obszar nadzwyczajnych sytuacji, a takie przecież ze swej natury wymagają nadzwyczajnych metod i środków.

Pozostaje jeszcze jedna kwestia — realności wykonania zadań z obszaru zarządzania kryzysowego. Wydaje się, że w odniesieniu do prezydenta miasta stołecznego Warszawy, prezydentów miast na prawach powiatów, starostów, wojewodów czy wreszcie Rady Ministrów nie występują jakieś istotne problemy w tym względzie. W odniesieniu zaś do wójtów, burmistrzów, prezydentów miast (z wyłączeniem miast na prawach powiatów) pojawiają się jednakże, jak sądzę, pewne wątpliwości. Należy przecież zauważyć, że nie wszystkie gminy mają odpowiedni poziom ekonomiczny, kadrowy, organizacyjny, gwarantujący stosowny, wysoki poziom profesjonalizmu planowania cywilnego, właściwą sprawność monitorowania zagrożeń, zapewnienie całodobowego alarmowania członków gminnego zespołu zarządzania kryzysowego (jeśli takowy zostanie powołany), a w sytuacjach kryzysowych całodobowych dyżurów — stałych dyżurów na potrzeby obronności państwa. Dotyczy to przede wszystkim słabych gmin wiejskich, w których niejednokrotnie jedynym podmiotem mogącym w miarę profesjonalnie uczestniczyć w zarządzaniu kryzysowym jest Ochotnicza Straż Pożarna. Trudno w tym kontekście nie zgodzić się z opinią S. Pieprznego, że „W tej sytuacji, nawet pobieżne skonfrontowanie zadań wójta $\mathrm{w}$ zakresie zarządzania kryzysowego z możliwościami gminy wiejskiej wskazuje na iluzoryczny ich charakter"24. Problem ten bez wątpienia wymaga odrębnego potraktowania, wykraczającego jednakże poza przyjęte ramy tego opracowania.

\title{
THE ROLE OF LOCAL PUBLIC ADMINISTRATION IN PREVENTING CRISIS SITUATIONS
}

\begin{abstract}
Summary
Crisis management is a specific area of public safety protection. Competent authorities in this area include on the one hand, Council of Ministers and on the other, territorial (local) authorities belonging both to local administration (voivodes) and local government (district governors and municipal executive officers/town mayors/city presidents). The territorial (local) authorities play a critical role here as they are a specific structure set up for crisis management.
\end{abstract}

${ }^{24}$ S. Pieprzny, System zarządzania kryzysowego, s. 48; zob. także E. Bonusiak, Zarzadzanie kryzysowe w gminie, [w:] Bezpieczeństwo wewnętrzne państwa, s. 308-309. 